


\section{Where the World Ended}

RE-UNIFICATION AND IDENTITY

IN THE GERMAN BORDERLAND

DAPHNE BERDAIIL

UNIVERSITY OF CALIFORNIA PRESS

Berkeley Los Angeles London 
An earlier version of chapter 7 appeared in A User's Guide to German Cultural Studies, edited by Scott Denham, Irene Kacandes, and Jonathan Petropolous. Ann Arbor: University of Michigan Press, 1997.

University of California Press

Berkeley and Los Angeles, California

University of California Press, Ltd.

London, England

(C) 1999 by the Regents of the University of California

Library of Congress Cataloging-in-Publication Data

Berdahl, Daphne.

Where the world ended : re-unification and identity in the German borderland / Daphne Berdahl.

p. $\mathrm{cm}$.

Includes bibliographical references and index ISBN 978-0-520-2 I 477-4 (pbk. : alk. paper)

1. Germany (East)-Boundaries-Case studies. 2. GermanyHistory - Unification, 1990-Case studies. 3. Ethnology-

Germany-Case studies. 4. Kella (Germany)-Case studies.

5. Kella (Germany) - Social life and customs - 2oth century.

6. Social change--Germany-Kella. I. Title.

DD289.5 D47 1999

$341.4^{\prime} 2-\mathrm{dc} 21$

Printed in the United States of America

1211

$\begin{array}{llll}11 & 10 & 9 & 8\end{array}$

The paper used in this publication meets the minimum requirements of ANSI/ NISO Z39.48-1992 (R 1997) (Pernanence of Paper). () 
For John

and

the people of Kella 
